\title{
Pertanggungjawaban Hukum Perawat Dalam Hal Pemenuhan Kewajiban Dan Kode Etik Dalam Praktik Keperawatan
}

\author{
Baiq Setiani \\ Program Studi Ilmu Hukum \\ Fakultas Hukum Universitas Azzahra \\ Jl. Jatinegara Barat No. 144, Kp. Melayu, Jakarta Timur 13320 \\ Email : baiqsetiani@yahoo.com
}

\begin{abstract}
Abstrak
Perawat merupakan tenaga kesehatan yang paling banyak di Indonesia. Tenaga keperawatan yang melakukan tindakan keperawatan harus sesuai dengan kompetensi perawat yang sudah ditetapkan dan didapatkan selama proses pendidikan. Oleh karena itu, tanggung jawab hukum seorang perawat dalam menjalankan praktik mandiri keperawatan harus sesuai dengan standar pelayanan perawat, standar profesi, standar operasional dan kebutuhan kesehatan penerima pelayanan kesehatan. Metode dalam penelitian ini menggunakan pendekatan yuridis normatif, yaitu pendekatan perundang-undangan, pendekatan konseptual dan pendekatan kasus yang pernah terjadi.
\end{abstract}

Kata kunci $\quad$ : Kewajiban, Kode Etik, Perawat, Pelayanan, Tanggung Jawab.

\begin{abstract}
Nurses are the most health workers in Indonesia. nursing personnel who perform nursing act should be in accordance with the competence of nurses who have been assigned and obtained during the process of education. therefore, the legal responsibility of a nurse in running the independent practice of nursing must be in accordance with nursing service standards, professional standards, operational standards and the health needs of the patient. the method in this research using normative juridical approach, namely statute aprroach, conceptual approach and case approach that ever happened.
\end{abstract}

Keywords $\quad$ : Duty, Ethic Code, Nurse, Responsibility, Service. 


\section{Pendahuluan}

Perawat merupakan tenaga kesehatan yang paling banyak di Indonesia. Dalam Kepmenkes RI No. 1239 Tahun 2001 tentang Registrasi dan Praktik Perawat, disebutkan bahwa perawat adalah "Seseorang yang telah lulus pendidikan tinggi keperawatan, baik di dalam maupun di luar negeri yang diakui oleh pemerintah sesuai dengan ketentuan peraturan perundang-undangan". Tenaga keperawatan yang melakukan tindakan keperawatan harus sesuai dengan kompetensi perawat yang sudah ditetapkan dan didapatkan selama proses pendidikan. Oleh karena itu, tanggung jawab hukum seorang perawat dalam menjalankan praktik mandiri keperawatan harus sesuai dengan standar pelayanan perawat, standar profesi, standar operasional dan kebutuhan kesehatan penerima pelayanan kesehatan.

Dewasa ini, perkembangan keperawatan dunia menjadi acuan bagi perawat untuk melakukan perubahan mendasar dalam kegiatan profesinya. Pekerjaan perawat yang semula vokasional bergeser menjadi pekerjaan profesional. Perawat yang dulunya berfungsi sebagai perpanjangan tangan dokter, menjadi bagian dari upaya mencapai tujuan pelayanan klinis, kini mereka menginginkan pelayanan keperawatan mandiri sebagai upaya mencapai tujuan asuhan keperawatan. ${ }^{1}$

Perawat dalam melakukan praktik keperawatan diharuskan menjunjung asas etik dan profesionalisme. Aspek etik merupakan salah satu pondasi yang sangat penting bagi perawat dalam membangun hubungan baik dengan semua pihak selama melakukan pelayanan keperawatan. Hubungan baik dengan semua pihak yang berperan dalam pelayanan kesehatan dapat mempermudah dalam mencapai tujuan bersama, yaitu kesembuhan dan kepuasan pasien. Interaksi perawat dengan pasien sangat dibutuhkan dalam proses pelayanan keperawatan demi tercapainya kerekatan dan kekeluargaan.

Masalah etik keperawatan sebagian besar terjadi pada pelaksanaan pelayanan keperawatan. Rasa ketidakpuasan yang sering kali timbul pada pasien adalah pasien merasa kebutuhannya tidak dipenuhi dan merasa tidak diperhatikan oleh perawat dalam pelayanan kesehatan. Masalah etik yang sering muncul menyebabkan konflik antar tenaga kesehatan dengan tenaga kesehatan yang lain maupun dengan pasien, sesuai dengan buku etik keperawatan dengan penekatan praktik dijelaskan bahwa permasalahan etis yang dihadapi perawat dalam melaksanakan praktik keperawatan telah menimbulkan konflik antara kebutuhan pasien dengan harapan perawat dan falsafah perawat. ${ }^{2}$

Kode etik keperawatan merupakan salah satu pegangan seorang perawat untuk mencegah terjadinya kesalahpahaman dan konflik yang terjadi. Kasus pelanggaran etik keperawatan yang terjadi di rumah sakit yaitu perawat melanggar aspek etik autonomy perawat, seperti kasus kisah bayi prematur Evan yang meninggal setelah disuntik perawat. ${ }^{3}$ Perawat dalam kasus ini tidak meminta persetujuan kepada keluarga pasien sebelum melakukan tindakan penyuntikan, seperti yang dikatakan oleh keluarga dari pasien tersebut. Perawat disini juga melanggar aspek etik perawat veracity, dimana perawat tidak mengatakan secara jujur suntikan apa yang diberikan kepada pasien.

Kasus pelanggaran etik keperawatan lain yang juga terjadi kepada pasien, yaitu pada kasus akibat kelalaian perawat, kaki bayi usia enam hari melepuh dicelup ke air mendidih. Kasus ini menunjukkan pelanggaran etik keperawatan non-maleficence, dimana tindakan perawat yang dilakukan merugikan orang lain dan membahayakan nyawa dari orang tersebut. ${ }^{4}$

Hubungan hukum antara perawat dan pasien dimulai secara keperdataan. Untuk melihat atau mendudukkan hubungan perawat dengan pasien yang mempunyai landasan hukum, dapat dimulai dengan Pasal 1367 KUH Perdata dinyatakan :"Seseorang tidak hanya bertanggung jawab atas kerugian yang disebabkan atas perbuatannya sendiri, melainkan juga atas kerugian yang disebabkan perbuatan-perbuatan orang-orang yang menjadi tanggungannya atau disebabkan orang-orang yang berada dibawah pengawasannya". Ketika kerugian yang diderita pasien akibat tindakan tersebut berakibat fatal, maka disinilah muncul permasalahan hukum, khususnya di bagian hukum perdata dalam rumusan Pasal 1365 KUH Perdata tentang perbuatan melawan hukum yang berbunyi "Tiap perbuatan yang melanggar hukum dan membawa kerugian kepada orang lain, mewajibkan orang yang menimbulkan kerugian itu karena kesalahannya untuk menggantikan tersebut". 
Oleh karena itu, sehubungan dengan kerugian pasien yang disebabkan pelanggaran etik keperawatan dalam menjalankan tugas dan wewenangnya, maka pasien selaku konsumen pengguna jasa mempunyai hak yang tidak boleh dilanggar oleh siapapun juga, termasuk perawat selaku pemberi pelayanan jasa kesehatan. Berdasarkan pada paparan yang telah diuraikan di atas, penulis tertarik untuk membuat sebuah penelitian dengan judul "Pertanggungjawaban Hukum Perawat Dalam Pemenuhan Kewajiban dan Kode Etik Ditinjau Dalam Praktik Keperawatan". Dari judul tersebut, dapat dirumuskan pokok masalah yaitu :

1) Bagaimana tanggung jawab perawat sebagai tenaga kesehatan;

2) Tanggung jawab perawat dalam melakukan kewajiban dan hak berdasarkan peraturan perundang-undangan; dan

3) Tanggung jawab perawat dalam pelanggaran etik keperawatan.

\section{Metode}

Metode dalam penelitian ini menggunakan pendekatan yuridis normatif, yaitu pendekatan pada peraturan perundangundangan (statute approach), pendekatan konseptual (conceptual approach) dan pendekatan kasus (case approach) yang pernah terjadi. Sumber data dalam penelitian ini menggunakan bahan hukum primer, bahan hukum sekunder dan bahan hukum tersier. Sedangkan pengumpulan bahan hukum dilakukan dengan studi pustaka terhadap bahan-bahan hukum dan analisis hukum dilakukan secara bertahap dengan metode deduktif.

\section{Hasil Dan Pembahasan}

\section{Tanggung Jawab Perawat Sebagai Tenaga Kesehatan}

Pasal 1 angka 2 Undang-Undang No. 36 Tahun 2009 disebutkan bahwa "Sumber daya di bidang kesehatan adalah segala bentuk dana, tenaga, perbekalan kesehatan, sediaan farmasi dan alat kesehatan serta fasilitas pelayanan kesehatan dan teknologi yang dimanfaatkan untuk menyelenggarakan upaya kesehatan yang dilakukan oleh Pemerintah, pemerintah daerah, dan/atau masyarakat", 11 Sedangkan dalam Pasal 1 ayat 6 Undang-Undang No. 36 Tahun
2009 tentang Kesehatan menyatakan bahwa "Tenaga kesehatan adalah setiap orang yang mengabdikan diri dalam bidang kesehatan serta memiliki pengetahuan dan/atau keterampilan melalui pendidikan di bidang kesehatan yang untuk jenis tertentumemerlukan kewenangan untuk melakukan upaya kesehatan". ${ }^{11}$

Upaya kesehatan adalah setiap kegiatan dan/atau serangkaian kegiatan yang dilakukan secara terpadu, terintregasi dan berkesinambungan untuk memelihara dan meningkatkan derajat kesehatan masyarakat dalam bentuk pencegahan penyakit, peningkatan kesehatan, pengobatan penyakit, dan pemulihan kesehatan oleh pemerintah dan/atau masyarakat. (Pasal 1 angka 11 Undang-Undang No. 36 Tahun 2009). ${ }^{11}$

Tenaga kesehatan, bila ditinjau dari Pasal 2 Peraturan Pemerintah No. 32 Tahun 1996 tentang Tenaga Kesehatan, meliputi :

1) Tenaga medis;

2) Tenaga keperawatan;

3) Tenaga kefarmasian;

4) Tenaga kesehatan masyarakat;

5) Tenaga gizi;

6) Tenaga keterapian fisik; dan

7) Tenaga keteknisian medis.

Dan di dalam penjelasan pasal tersebut, disebutkan bahwa yang termasuk tenaga keperawatan adalah perawat dan bidan.

Kewenangan Perawat dalam menjalankan tugas dan profesinya secara prinsip diatur dalam Keputusan Menteri Kesehatan RI No. 1293/Menkes/SK/XI/2001 tentang Registrasi dan Praktik Perawat. Keputusan Menteri ini sebagai peraturan tekhnis yang diamanatkan UU Kesehatan Tahun 1992 dan peraturan pelaksanaan dari Peraturan Pemerintah No. 32 Tahun 1996 tentang Tenaga Kesehatan. Dalam Peraturan Pemerintah No. 32 Tahun 1996 tersebut dijabarkan bahwa perawat merupakan salah satu tenaga kesehatan yang memiliki kewenangan dan fungsi khusus yang berbeda dengan tenaga kesehatan lain. Dengan demikian sebagai peraturan pelaksana, Keputusan ini merupakan norma yuridis yang mengikat perawat dalam menjalankan profesinya, terutama yang dilakukan di rumah sakit.

Dalam menjalankan profesinya maka perawat tidak akan terlepas dari batasan kewenangan yang dimiliknya. Karena menurut 
Prof. Leenan seperti yang telah dikutip dalam bab terdahulu, bahwa kewenangan merupakan syarat utama dalam melakukan suatu tindakan medis. Pasal 15 Kepmenkes RI No. 1293/Menkes/SK/XI/2001 menyebutkan batasan kewenangan tersebut yaitu:

1) Melaksanakan asuhan keperawatan yang meliputi pengkajian, penetapan diagnosa keperawatan, perencanaan, melaksanakan tindakan keperawatan dan evluasi keperawatan;

2) Tindakan perawat sebabaimana dimaksud pada butir a meliputi intervensi keperawatan, observasi keperawatan, pendidikan, dan konseling kesehatan;

3) Dalam melaksanakan asuhan keperawatan sebagaimana dimaksud huruf (a) dan (b) harus sesuai dengan standar asuhan keperawatan yang ditetapkan oleh organisasi profesi;

4) Pelayanan tindakan medik hanya dapat dilakukan berdasarkan perintah tertulis dari dokter.

Dalam menjalankan kewenangan tersebut, ada kewajiban yang patut diingat oleh perawat. Kewajiban tersebut terdapat dalam Pasal 16 yaitu:

1) Menghormati hak pasien;

2) Merujuk kasus yang tidak dapat ditangani;

3) Menyimpan rahasia sesuai dengan peraturan perundang-undangan yang berlaku;

4) Memberikan informasi;

5) Meminta persetujuan tindakan yang akan dilakukan;

6) Melakukan catatan perawatan dengan baik.

Meskipun demikian ada pengecualian terhadap kewenangan yang telah dilandaskan pada Pasal 15 tersebut. Pengecualian tersebut jelas dimaksudkan untuk memberikan perlindungan hukum yang lebih luas terhadap penyelenggaran dan pelayanan kesehatan yang dilakukan seorang perawat. Ketentuan tentang pengecualian tersebut terdapat dalam Pasal 20 yakni:

1) Dalam keadaaan darurat yang mengancam jiwa seseorang/pasien, perawat berwenang untuk melakukan pelayanan kesehatan diluar kewenangannya sebagaimana dimaksud dalam Pasal 15.

2) Pelayanan dalam keadaan darurat sebagaimana dimaksud pada ayat (1) ditujukan untuk penyelamatan jiwa.

Pengaturan kewenangan perawat tersebut lebih lanjut dijelaskan dalam Petunjuk
Pelaksana Kepmenkes RI No. 1239/Menkes/2001 yang merupakan suatu pedoman untuk melaksanakan registrasi praktek kepeawatan. Pada petunjuk pelaksanaan tersebut disebutkan bahwa kewenangan perawat adalah melakukan asuhan keperawatan yang meliputi kondisi sehat dan sakit yang mencakup; asuhan keperawatan pada perinatal, asuhan keperawatan pada neonatal, asuhan keperawatan pada anak, asuhan keperawatan pada dewasa, dan asuhan keperawatan pada maternitas.

\begin{tabular}{|c|c|c|}
\hline \multicolumn{3}{|c|}{ Jawab Perawat dalam } \\
\hline Melaksanakan & Kewajiban & dan \\
\hline $\begin{array}{l}\text { Berdasarkan } \\
\text { undangan }\end{array}$ & Peraturan & Perundang- \\
\hline
\end{tabular}

\section{Dalam Undang-Undang No. 38 Tahun 2014 tentang Keperawatan}

Kewajiban adalah sesuatu yang harus diperbuat atau harus dilakukan sesorang atau suatu Badan Hukum. Kewajiban merupakan sesuatu yang wajib dilaksanakan, kewajiban dibagi diatas terdapat dua macam yaitu kewajiban sempurna yang selalu berkaitan dengan hak orang lain dan kewajiban yang tidak sempurna yang terkait dengan hak orang lain. Kewajiban sempurna mempunyai dasar keadilan, sedangkan kewajiban tidak sempurna berdasarkan moral, kewajiban merupakan segala bentuk beban yang diberikan oleh hukum kepada orang ataupun Badan Hukum. Kewajiban yang dimaksud disini adalah kewajiban perawat yang melaksanakan praktik mandiri perawat, dimana perawat, baik di fasilitas kesehatan maupun di rumah pasien. ${ }^{12}$

Perawat adalah seseorang yang telah menyelesaikan program pendidikan keperawatan, berwenang di Negara yang bersangkutan untuk memberikan pelayanan, dan bertanggung jawab dalam peningkatan kesehatan, pencegahan penyakit, serta pelayanan terhadap pasien. Oleh karena itu, perawat dalam menjalankan praktik mandiri perawat, berkewajiban memiliki Surat Tanda Registrasi (STR) dan Surat Izin Praktik Perawat (SIPP).

Ketentuan dalam Pasal 37 UndangUndang No. 38 Tahun 2014 tentang Keperawatan, mewajibkan perawat untuk melengkapi prasarana pelayanan keperawatan sesuai dengan standar pelayanan keperawatan, memberikan pelayanan, merujuk pasien 
kepada perawat lain jika perawat tidak dapat menangani, mendokumentasikan asuhan keperawatan, memberikan informasi yang lengkap, jujur, benar, jelas dan mudah dimengerti oleh pasien tentang tindakan keperawatan yang akan diberikan kepadanya sesuai dengan batas kewenangan perawat, melaksanakan pelimpahan wewenang dari tenaga kesehatan lain seperti dokter dengan syarat memberikan delegasi secara tertulis dari dokter.

Dengan demikian perawat melaksanakan standar pelayanan keperawatan, sehingga bila terjadi suatu kesalahan/kelalaian, maka perawat dapat bertanggung jawab. Oleh karena itu, lahirnya hak dan kewajiban perawat, maka hubungan anggota masyarakat dilindungi oleh hukum, maka mereka harus mentaati hubungan hukum ini. Kehendak untuk mentaati hubungan hukum ini disebut tanggung jawab hukum (legal liability). Tanggung jawab hukum dimaksudkan sebagai terhadap ketetntuan-ketentuan hukum. Seorang perawat dalam memberikan jasa pelayanan kemungkinan melakukan kesalahan/kelalaian. Hal ini akan menimbulkan tuntutan terhadap perawat oleh pasien maupun keluarganya agar perawat bertanggung jawab.

Apabila perawat melaksanakan kewajibannya dengan baik, maka perawat berhak memperoleh haknya sebagaimana dalam Pasal 36 Undang-Undang Nomor 38 Tahun 2014 tentang Keperawatan yang menyatakan bahwa "Perawat berhak memperoleh perlindungan hukum sepanjang melaksanakan kewajibannya sesuai dengan standar pelayanan keperawatan, mendapatkan informasi yang benar, lengkap dan jujur dari pasien atau keluarganya mengenai kondisi atau penyakit pasien, agar perawat tidak melakukan kesalahan/kelalaian dalam menentukan diagnosa penyakit pasien dan tidak salah menentukan obat yang akan diberikan padanaya, menolak keinginan pasien yang tidak sesuai dengan standar pelayanan keperawatan serta perawat berhak mendapatkan imbalan jasa dari pelayanan yang diberikan oleh pasien dan memperoleh fasilitas kerja sesuai dengan standar".

Jika perawat melakukan suatu kesalahan atau kelalaian yang menyebabkan pasien mengalami kerugian dalam menjalankan praktik mandiri perawat, maka perawat harus bertanggung jawab untuk menerima sanksi administrasi sebagaimana dalam Pasal 58 Ayat
(1) Setiap orang yang melanggar ketentuan Pasal 18 Ayat (1), Pasal 21, Pasal 24 Ayat (1), dan Pasal 27 Ayat (1) dikenai sanksi administrasi; Ayat (2) Sanksi administrasi sebagaimana dimaksud pada Ayat (1) dapat berupa : a) teguran lisan; b) peringatan tertulis; c) denda administratif dan; d) pencabutan izin praktik; Ayat (3) Ketentuan lebih lanjut mengenai tata cara pengenaan sanksi administratif sebagaimana dimaksud pada Ayat (2) diatur dengan Peraturan Pemerintah.

\section{Dalam Undang-Undang No. 36 Tahun 2009 tentang Kesehatan}

Kewajiban perawat dalam UndangUndang No. 36 Tahun 2009 tentang Kesehatan, dapat dilihat dari beberapa pasal berikut:

Pasal 9 : (1) Setiap orang berkewajiban, mewujudkan,

mempertahankan, dan mening- katkan derajat kesehatan masyarakat yang setinggi-tingginya;

(2) Kewajiban sebagaimana dimaksud pada Ayat (1), pelaksanaannya meliputi upaya kesehatan perorangan, upaya kesehatan masyarakat, dan pembangunan berwawasan kesehatan;

Pasal 10 : Setiap orang berkewajiban menghormati hak orang lain, dalam upaya memperoleh lingkungan yang sehat, baik fisik, biologi, maupun sosial;

Pasal 11: Setiap orang berkewajiban berperilaku hidup sehat untuk mewujudkan, mempertahankan dan memajukan kesehatan yang setinggi-tingginya;

Pasal 12 : Setiap orang berkewajiban menjaga dan meningkatkan derajat kesehatan bagi orang lain yang menjadi tanggungjawabnya; dan

Pasal 13 : (1) Setiap orang berkewajiban turut serta dalam program jaminan kesehatan sosial;

(2) Program jaminan kesehatan sosial sebagaimana dimaksud pada Ayat (1) dikhususkan pada pelayanan publik. ${ }^{11}$

Kewajiban perawat dapat dinyatakan : (1) Perawat wajib mematuhi peraturan Institusi yang bersangkutan; (2) Perawat wajib 
memberikan pelayanan atau asuhan keperawatan sesuai dengan standar dan batas kewenangan; (3) Perawat wajib menghormati hak pasien; (4) Perawat wajib merujuk pasien kepada perawat atau tenaga kesehatan lain yang mempunyai keahlian atau kemampuan yang lebih baik bila yang bersangkutan tidak dapat mengatasinya; (5) Perawat wajib memberikan kesempatan kepada pasien untuk berhubungan dengan keluarganya selama tidak bertentangan dengan peraturan atau standar profesi yang ada; (6) Perawat wajib memberikan kesempatan kepada pasien untuk menjalankan ibadahnya sesuai dengan agama atau kepercayaan masing-masing selama tidak mengganggu pasien lainnya; (7) Perawat wajib berkolaborasi dengan tenaga medis atau tenaga kesehatan terkait lainnya dalam memberikan pelayanan kesehatan dan pelayanan keperawatan kepada pasien.

Perawat merupakan salah satu profesi tenaga kesehatan yang memberikan pelayanan kesehatan langsung baik kepada individu, keluarga dan masyarakat. Sebagai salah satu tenaga profesional, perawat menjalankan dan melaksanakan kegiatan praktik keperawatan dengan menggunakan ilmu pengetahuan dan teori keperawatan yang dapat dipertanggungjawabkan. Dimana ciri sebagai profesi adalah mempunyai body of knowledge yang dapat diuji kebenarannya serta ilmunya dapat diimplementasikan kepada masyarakat langsung.

Sedangkan ketentuan dalam Pasal 56 Undang-Undang No. 36 Tahun 2009 tentang Kesehatan dinyatakan hak-hak perawat, yaitu:

1) Perawat berhak untuk mendapatkan perlindungan hukum dalam melaksanakan tugas sesuai dengan profesinya;

2) Perawat berhak mengembangkan diri melalui kemajuan sosialisasi sesuai dengan latar belakang pendidikannya;

3) Perawat berhak menolak keinginan pasien yang bertentangan dengan peraturan perundang-undangan serta standar dan kode etik profesi perawat;

4) Perawat berhak mendapatkan ilmu pengetahuan berdasarkan perkembangan ilmu pengetahuan dan teknologi dalam bidang keperawatan atau kesehatan secara terus menerus;

5) Perawat berhak untuk mendapatkan penghargaan dan imbalan yang layak atas jasa profesi yang diberikannya berdasarkan perjanjian atau ketentuan yang berlaku di Institusi pelayanan yang bersangkutan.

Dalam Peraturan Menteri Kesehatan RI No. HK.02.02/Menkes/148/I/2010 tentang Izin dan Penyelenggaraan Praktik Perawat

Di dalam Permenkes ini, kewajiban perawat diatur dalam Pasal 3 dan 12. Dalam Pasal 3 disebutkan bahwa "Setiap perawat yang menjalankan praktik wajib memiliki SIPP". ${ }^{10}$ Namun ternyata terdapat kesenjangan antara kondisi ideal dengan kenyataan. Di berbagai daerah di Indonesia ditelusuri adanya perawat yang membuka praktik mandiri tanpa memiliki SIK dan SIPP. Menurut Bangka Pos, berdasarkan catatan Persatuan Perawat Nasional Indonesia (PPNI) Bangka Belitung, dari 300 perawat di kota Pangkal Pinang belum satupun yang memiliki SIK dan SIPP. Padahal banyak yang memberikan pengobatan medis kepada masyarakat. Demikian juga yang diberitakan Batam Pos adanya perawat yang diperiksa oleh Polsek setempat karena membuka praktik perawat tanpa izin dari Dinas Kesehatan setempat. $^{5}$

Sedangkan itu, kewajiban perawat dalam Pasal 12 dinyatakan bahwa "(1) dalam melaksanakan praktik, perawat wajib untuk :

a) Menghormati hak klien;

b) Melakukan rujukan;

c) Menyimpan rahasia sesuai peraturan perundang-undangan;

d) Memberikan informasi tentang masalah kesehatan pasien/klien dan pelayanan yang dibutuhkan;

e) Meminta persetujuan tindakan keperawatan yang akan dilakukan;

f) Melakukan pencatatan asuhan keperawatan secara sistematis; dan

g) Mematuhi standar".

Kewajiban perawat tersebut menjadi hak bagi pasien. Dengan begitu, hubungan antara perawat dan pasien merupakan hubungan hukum (perjanjian) yang menimbulkan hak dan kewajiban bagi masing-masing pihak. Oleh karena itu, aspek keperdataan dalam pelayanan keperawatan berpokok pangkal pada hubungan perawat dan pasien.

Adapun mengenai hak diatur dalam Pasal 11 yang berbunyi "Dalam melaksanakan praktik, perawat mempunyai hak :

1) Memperoleh perlindungan hukum dalam melaksanakan praktik keperawatan sesuai standar; 
2) Memperoleh informasi yang lengkap dan jujur dari klien dan/atau keluarganya;

3) Melaksanakan tugas sesuai dengan kompetensi;

4) Menerima imbalan jasa profesi; dan

5) Memperoleh jaminan perlindungan terhadap resiko kerja yang berkaitan dengan tugasnya".

\section{Tanggung Jawab Hukum Perawat dalam Pelanggaran Etik Keperawatan}

Kode Etik adalah sistem norma, nilai dan aturan profesional tertulis yang secara tegas menyatakan benar dan baik, serta yang tidak benar dan tidak baik bagi profesi. Kode etik perawat adalah pernyataan standar profesional yang digunakan sebagai pedoman perilaku dan menjadi kerangka kerja untuk membuat keputusan keperawatan. Aturan yang berlaku untuk seorang perawat Indonesia dalam melaksanakan tugas serta fungsi perawat adalah kode etik perawat nasional Indonesia, dimana seorang perawat selalu berpegang teguh terhadap kode etik sehingga kejadian akan pelanggaran kode etik dapat dihindarkan dan diminimalisasi.

Kode etik perawat (juga biasa disebut etik keperawatan) sebagai bagian dari pengetahuan dasar etik berisi bagaimana perawat seharusnya berperilaku etik sebagai sebuah profesi, bagaimana seharusnya membuat keputusan saat mengalami hambatan, bagaimana mencegah terjadinya permasalahan etik, serta bagaimana berusaha memenuhi kewajiban profesional sersuai tujuan, nilai dan standar keperawatan. ${ }^{6}$ Etik keperawatan mengandung unsur-unsur pengorbanan, dedikasi, pengabdian, dan hubungan antara perawat dengan klien, dokter, sejawat perawat, diri sendiri, keluarga klien, dan pengunjung. Etik keperawatan merupakan hal yang sangat penting dalam pelaksanaan pelayanan kesehatan. Selain bermanfaat bagi perawat, etik juga bermanfaat bagi tim kesehatan lainnya dan bagi penerima pelayanan kesehatan. $^{7}$ Etik keperawatan ini juga bermanfaat bagi rumah sakit terutama untuk meningkatkan kualitas pelayanan kesehatan dan meningkatkan mutu pelayanan rumah sakit.

Perawat yang berada di samping pasien selama 24 jam memiliki peran penting terhadap segala sesuatu yang terjadi pada pasien. Meskipun perawat sering berada di samping pasien, interaksi antara perawat dengan pasien perlu diperbaiki kembali. Terkadang walaupun perawat berada disamping pasien selama 24 jam, masih ada beberapa perawat yang mengabaikan etik keperawatan terhadap pasien. Berangkat dari hal semacam inilah menjadi penyebab lahirnya pelanggaran kode etik keperawatan, yaitu perawat sebagai profesi tenaga pelayanan keperawatan kurang memahami apa arti dari kode etik keperawatan, sehingga berdampak pada keselamatan pasien. Oleh karena itu, sebagai perawat harus memahami pentingnya kode etik keperawatan agar dapat memberikan pelayanan yang baik kepada klien.

Di dalam Buku Standar Kode Etik Keperawatan, disebutkan beberapa jenis pelanggaran etik keperawatan, antara lain: ${ }^{7}$

1. Pelanggaran ringan, meliputi :

(a) melalaikan tugas;

(b) berperilaku tidak menyenangkan penderita atau keluarga;

(c) tidak bersikap sopan saat berada dalam ruang perawatan;

(d) tidak berpenampilan rapi;

(e) menjawab telepon tanpa menyebutkan identitas; dan

(f) berbicara kasar dan mendiskreditkan teman sejawat dihadapan umum/forum.

2. Pelanggaran sedang, meliputi :

(a) meminta imbalan berupa uang atau barang kepada pasien atau keluarganya untuk kepentingan pribadi atau kelompok;

(b) memukul pasien dengan sengaja;

(c) bagi perawat yang sudah menikah dilarang menjalin cinta dengan pasien dan keluarganya, suami atau teman sejawat;

(d) menyalahgunakan uang perawatan atau pengobatan pasien untuk kepentingan pribadi atau kelompok;

(e) merokok dan berjudi di lingkungan rumah sakit saat memakai seragam perawat;

(f) menceritakan aib teman seprofesi atau menjelekkan profesi perawat dihadapan profesi lain; dan

(g) melakukan pelanggaran etik ringan (minimal 3 kali).

3. Pelanggaran berat, meliputi :

(a) melakukan tindakan keperawatan tanpa mengikuti prosedur sehingga penderitaan pasien bertambah parah bahkan meninggal; 
(b) salah emmberikan obat sehingga berakibat fatal bagi pasien;

(c) membiarkan pasien dalam keadaan sakit parah atau sakratul maut tanpa memberikan pertolongan;

(d) berjudi atau meminum minuman beralkohol sampai mabuk diruangan perawatan;

(e) menodai kehormatan pasien;

(f) memukul atau berbuat kekerasan pada pasien dengan sengaja sampai terjadi cacat fisik;

(g) menyalahgunakan obat pasien untuk kepentingan pribadi atau kelompok; dan

(h) menjelekkan dan/atau membuat cerita hoax mengenai profesi keperawatan pada profesi lain dalam forum, media cetak, maupun media online yang mengakibatkan adanya tuntutan hukum.

Sedangkan sanksi untuk pelanggaran etik keperawatan terbagi atas :

1. Sanksi pelanggaran ringan, yaitu dengan :

(a) Berjanji untuk tidak mengulangi perbuatannya lagi; dan

(b) Meminta maaf terhadap pihak yang dirugikan.

2. Sanksi pelanggaran sedang, yaitu dengan :

(a) Harus mengembalikan barang atau uang yang diminta kepada pasien atau keluarganya;

(b) Meminta maaf terhadap pihak yang dirugikan; dan

(c) Membuat surat pernyataan diatas kertas segel bermaterai tidak akan mengulanginya lagi.

3. Sanksi pelanggaran berat, yaitu dengan :

(a) Harus meminta maaf terhadap pihak yang dirugikan;

(b) Membuat surat pernyataan diatas kertas segel bermaterai tidak akan mengulanginya lagi;

(c) Dilaporkan kepada pihak kepolisian; dan (d) diberhentikan dari kedinasan dengan tidak hormat.

Penanganan masalah etik keperawatan merupakan penanganan masalah yang dilakukan untuk menyelesaikan masalahmasalah yang berhubungan dengan pelanggaran masalah Kode Etik Keperawatan Indonesia. yang bertanggungjawab dalam masalah etik adalah ${ }^{8}$

1) Direktur Rumah Sakit;

2) Kepala Bidang Pelayanan Keperawatan;
3) Kepala Ruangan;

4) Ketua Komite Keperawatan melalui Sub Komite Etik Komite Keperawatan.

Untuk mekanisme penyelesaian masalah etik, meliputi : 1) membuat kronologis kejadian; 2) menilai bobot masalah (pelanggaran ringan, sedang, atau berat); 3) penyelesaian masalah secara berjenjang, yaitu Kepala Ruangan, Kepala Bidang Pelayanan Keperawatan, Direktur Rumah Sakit dengan melibatkan Sub Komite Etik Komite Keperawatan dan organisasi profesi (PPNI dan IBI). Setiap terjadi pelanggaran etik keperawatan dilakukan pencatatan dan pelaporan menggunakan formulir baku yang telah ditentukan, seperti Formulir Peringantan Lisan, Formulir Laporan Kejadian Pelanggaran Kode Etik Keperawatan, dan Formulir Pengarahan/Konseling. Kemudian setiap pelanggaran kode etik keperawatan terdapat nomor pelanggaran yang sesuai jenis pelanggaran etik keperawatan. ${ }^{9}$

Selanjutnya, tanggung jawab hukum perawat dapat ditinjau dari pembidangan hukum itu sendiri. Bila ditinjau berdasarkan hukum administrasi negara, maka tanggung jawab hukum itu akan bersumber pada masalah kewenangan yang dimilikinya. Bila tanggung jawab hukum itu berdasarkan hukum perdata, maka unsur terkait adalah ada tidaknya suatu perbuatan melawan hukum atau wanprestasi dan bila bersumber pada hukum pidana maka unsurnya adalah ada tidaknya suatu kesalahan terhadap perbuatan yang harus/tidak seharusnya dilakukan berdasarkan hukum tertulis maupun tidak tertulis.

Tanggung jawab perawat akan bergantung pada bentuk kewenangan yang dimiliki. Pada pelanggaran kewenangan atribusi yang merupakan fungsi independennya perawat, maka bila terjadi kesalahan dalam asuhan keperawatan tersebut perawat yang bersangkutan akan memikul beban pertanggungjawabannya sendiri. Contoh kasus, bila seorang perawat melakukan kesalahan ketika memandikan pasien bayi yang menyebabkan terjadinya faktur. Sementara apabila fungsi interdependen yang dilanggar maka perawat akan memikul beban tanggungjawab tersebut bersama-sama dengan dokter ketua tim dan rumah sakit yang memberikan tugas tersebut. Contoh kasus, apabila terjadi kesalahan perawat dalam menghitung jumlah kapas bulat di ruang operasi sesudah operasi yang mengakibatkan 
tertinggalnya kapas di dalam perut pasien tidak terdeteksi oleh dokter.

Tanggung jawab hukum di bidang perdata akan bersumber pada perbuatan melawan hukum atau wanprestasi. Namun kedua batasan pelanggaran hukum tersebut tetap tidak akan lepas dari pelaksanaan fungsi perawat. Tindakan perawat dapat dikatakan sebagai perbuatan melawan hukum apabila terpenuhinya unsur-unsur yang tertuang dalam Pasal 1365 KUH Perdata, yakni adanya kerugian nyata yang diderita sebagai akibat langsung dari perbuatan tersebut. Sementara tanggung jawab dalam kategori wanprestasi apabila terpenuhi unsur-unsur wanprestasi dalam Pasal 1234 KUH Perdata.

Tanggung jawab perawat bila dilihat dari ketentuan dalam KUH Perdata, maka dapat dikatagorikan ke dalam empat prinsip sebagai berikut:

1. Tanggung jawab langsung berdasarkan Pasal 1365 BW dan Pasal 1366 BW

Berdasarkan ketentuan pasal tersebut maka seorang perawat yang melakukan kesalahan dalam menjalanka fungsi independennya yang mengakibatkan kerugian pada pasien maka ia wajib memikul tanggung jawabnya secara langsung;

2. Tanggung jawab dengan asas respondeat superior atau let's the master answer maupun khusus di ruang bedah dengan asas the captain of ship melalui Pasal 1367 BW

Dalam hal ini tanggung jawab akan muncul apabila kesaalahan terjadi dalam menjalankan fungsi interdependen perawat. Sebagai bagian dari tim maupun orang yang bekerja di bawah perintah dokter/rumah sakit, maka perawat akan bersama-sama bertanggung gugat kepada kerugian yang menimpa pasien;

3. Tanggung jawab\ dengan asas zaakwarneming berdasarkan Pasal 1354 BW

Dalam hal ini konsep tanggung jawab terjadi seketika bagi seorang perawat yang berada dalam kondidi tertentu harus melakukan pertolongan darurat dimana tidak ada orang lain yang berkompeten untuk itu. Perlindungan hukum dalam tindakan zaarneming perawat tersebut tertuang dalam Pasal 20 Kepmenkes tentang Registrasi Perawat. Perawat justru akan dimintai pertanggungjawaban hukum apabila tidak mengerjakan apa yang seharusnya dikerjakan dalam Pasal 20 tersebut;

4. Tanggung jawab karena gugatan wanprestasi berdasarkan Pasal 1234 BW

Dalam wanprestasi seorang peraawat akan dimintai pertanggungjawaban apabila terpenuhi unsur-unsur wanprestasi, yaitu:

a. Tidak mengerjakan kewajibannya sama sekali; dalam konteks ini apabila seorang perawat tidak mengerjakan semua tugas sesuai dengan fungsinya, baik fungsi independen, interdependen maupun dependen.

b. Mengerjakan kewajiban tetapi terlambat; dalam hal ini apabila kewjiban sesuai fungsi tersebut dilakukan terlambat yang mengakibatkan kerugian pada pasien. Contoh kasus seorang perawat yang tidak membuang kantong urine pasien dengan kateter secara rutin setiap hari. Melainkan 2 hari sekali dengan ditunggu sampai penuh. Tindakan tersebut megakibatkan pasien mengalami infeksi saluran urine dari kuman yang berasal dari urine yang tidak dibuang.

c. Mengerjakan kewajiban tetapi tidak sesuai dengan yang seharusnya; suatu tugas yang dikerjakan asal-asalan. Sebagai contoh seorang perawat yang mengcilkan aliran air infus pasien di malam hari hanya karena tidak mau terganggu istirahatnya.

d. Mengerjakan yang seharusnya tidak boleh dilakukan; dalam hal ini apabila seorang perawat melakukan tindakan medis yang tidak mendapat delegasi dari dokter, seperti menyuntik pasien tanpa perintah, melakukan infus padahal dirinya belum terlatih.

Apabila perawat terbukti memenuhi unsur wanprestasi, maka tanggung jawab itu akan dipikul langsung oleh perawat yang bersangkutan.

Sementara dari aspek tanggung jawab secara hukum pidana seorang perawat baru dapat dimintai pertanggungjawaban apabila terdapat unsur-unsur sebagai berikut:

a. Suatu perbuatan yang bersifat melawan hukum ; dalam hal ini apabila perawat melakukan pelayanan kesehatan di luar kewenangan yang tertuang dalam Pasl 15 Kepmenkes. 
b. Mampu bertanggung jawab, dalam hal ini seorang perawat yang memahami konsekuensi dan resiko dari setiap tindakannya dan secara kemampuan, telah mendapat pelatihan dan pendidikan untuk itu. Artinya seorang perawat yang menyadari bahwa tindakannya dapat merugikan pasien.

c. Adanya kesalahan (schuld) berupa kesengajaan (dolus) atau karena kealpaan (culpa). Kesalahan disini bergantung pada niat (sengaja) atau hanya karena lalai. Apabila tindakan tersebut dilakukan karena niat dan ada unsur kesengajaan, maka perawat yang bersangkutan dapat dijerat sebagai pelaku tindak pidana. Sebagai contoh seorang perawat yang dengan sadar dan sengaja memberikan suntikan mematikan kepada pasien yang sudah terminal. (disebut dengan tindakan euthanasia aktif)

d. Tidak adanya alasan pembenar atau alasan pemaaf; dalam hal ini tidak ada alasan pemaaf seperti tidak adanya aturan yang mengijinkannya melakukan suat tindakan, ataupun tidak ada alasan pembenar seperti resiko yang melekat dalam tindakan yang dilakukan. Misalnya resiko terjadinya odem (bengkak) sesudah jarum infus dicabut.Atau adanya rasa tidak nyaman bagi pasien yang menjalani kateter.

\section{Kesimpulan}

Pada prinsipnya perencanaan, pengadaan, pendayagunaan, pembinaan dan pengawasan mutu tenaga kesehatan ditujukan kepada seluruh tenaga kesehatan dalam menyelenggarakan upaya kesehatan. Tenaga kesehatan dapat dikelompokkan sesuai dengan keahlian dan kualifikasi yang dimiliki, antara lain meliputi tenaga medis, tenaga kefarmasian, tenaga keperawatan, tenaga kesehatan masyarakat dan lingkungan, tenaga gizi, tenaga keterapian fisik, tenaga keteknisian medis, dan tenaga kesehatan lainnya. Kewenangan Perawat dalam menjalankan tugas dan profesinya secara prinsip diatur dalam Keputusan Menteri Kesehatan RI No. 1293/Menkes/SK/XI/2001 tentang Registrasi dan Praktik Perawat. Dalam menjalankan profesinya maka perawat tidak akan terlepas dari batasan kewenangan yang dimiliknya.

Pemyataan kode etik perawat dibuat untuk membantu dalam pembuatan standar dan merupakan pedoman dalam pelaksanaan tugas, kewajiban dan hak perawat profesional.
Kewajiban perawat tertuang dalam Pasal 37 Undang-Undang No. 38 Tahun 2014, Pasal 913 Undang-Undang No. 36 Tahun 2009, serta Pasal 3 dan 12 Peraturan Menteri Kesehatan RI No. HK.02.02/Menkes/148/I/2010. Sedangkan mengenai hak perawat, tertuang dalam Pasal 36 Undang-Undang Nomor 38 Tahun 2014, Pasal 56 Undang-Undang No. 36 Tahun 2009, serta Pasal 11 Peraturan Menteri Kesehatan RI No. HK.02.02/Menkes/148/I/2010.

Tanggung jawab hukum perawat bisa dipilah berdasarkan bidang hukum itu sendiri yakni secara hukum administrasi negara, secara hukum Perdata dan secara Hukum Pidana. Tanggung jawab secara HAN akan bersumber dari kewenangan yang diperoleh dan dihubungkan dengan fungsi perawat dalam menjalankan profesinya. Tanggung jawab secara hukum perdata akan bersumber pada perbuatan melawan hukum atau wanprestasi. Sedangkan tanggung jawab secara hukum pidana akan bersumber terhadap persyaratan untuk dapat dimintai tanggung jawab hukum.

\section{Saran}

Dalam pembuatan undang-undang praktik keperawatan, Pemerintah dan DPR perlu mengatur secara tegas tentang hak dan kewajiban perawatan dalam melakukan pelayanan kesehatan baik di rumah sakit, puskesmas, sarana kesehatan lain dan masyarakat. Disamping itu, dalam undangundang tersebut perlu diatur mengenai kewenangan dan kompetensi pelimpahan untuk melakukan tindakan medik kepada perawat, terutama yang bekerja di pedesaan dengan tetap memperhatikan doktrin locally rule.

\section{Daftar Pustaka}

1 "Model Praktik Keperawatan Profesional". http://giz-net.org. Indonesian Nutrition Network.

2 Haryono Rudi. Keperawatan Medikal Bedah: Sistem Perkemihan. Yogyakarta: Rapha Publishing, 2013. Hlm. 3.

3 "Kisah Bayi Prematur Evan, Meninggal Setelah Disuntik Perawat". http://m.merdeka.com/amp/ peristiwa/kisahbayi-prematur-evan-meninggal-setelahdisuntik-perawat.html.

4 "Akibat Kelalaian Perawat, Kaki Bayi Usia Enam Hari Melonyot Dicelup ke Air Mendidih". http://m.republika.co.id/amp/lmrcy2.

5 Cecep Tribowo, Hukum Keperawatan, Panduan Hukum dan Etika bagi Perawat. 
Yogyakarta: Pustaka Book Publisher, 2010. hlm. 62-63.

6 Numminen et al. Nurse Ethics. CINAHL Complete. Nurse Educators and Nursing Student Perspectives on Teaching Code of Ethics. 2009.

7 Persatuan Perawat Nasional Indonesia. Kode Etik Keperawatan Indonesia. Diakses dari www.ppni.or.id.

8 Konsep Etika dan Hukum Pelayanan Keperawatan. Pontianak, 2013. hlm. 6.
9 "Etika

Keperawatan”. http://keperawatankomit.blogspot.com/2014/03 letika-keperawatan.html ?m=1.

10 Peraturan Menteri Kesehatan RI No. HK.02.02/Menkes/148/I/2010 tentang Izin dan Penyelenggaraan Praktik Perawat.

11 Undang-Undang No. 36 Tahun 2009 tentang Kesehatan.

12 Undang-Undang Nomor 38 Tahun 2014 tentang Keperawatan. 